\title{
From occultism to hybrid Sufism: the transformation of an Islamic-hybrid spiritual group in contemporary Indonesia
}

\author{
Ahmad Muttaqin \\ Sunan Kalijaga State Islamic University, Yogyakarta Indonesia \\ E-mail:ahmad.muttaqin@uin-suka.ac.id,muttaqinsejati@gmail.com
}

\begin{abstract}
This paper discuses transformation of an Islamic-Hybrid Spiritual group, the Bhakti Nusantara (literally means 'devotion to nation'), from spiritualitas kasar [rough spirituality] of occult-based spirituality to the finer spirituality [spiritualitas alus] which is linked to Sufi spiritual practices. Based on my field work in Yogyakarta, in 2009 and 2010, the paper explains sociological context of group's institutional and spiritual transformation amid contemporary Islamic revival and modernizing process of the country. It then argues that the transformation of the group was driven by the logic for presenting spiritual heritages that are practically appropriate for modern life and which also fit religiously with orthodox Islam. Both the institutional transformation and the change of spiritual orientation of the group mark BN, as a hybrid spiritual group, to actively involve in the opportunities of modernity, instead of resisting the challenges and pressures of modern life.
\end{abstract}

Tulisan ini membahas proses transformasi dalam sebuah kelompok spiritualitas hybrida bernama Bhakti Nusantara (BN) dari "spiritualitas kasar" yang terkait 
dengan praktik klenik-kejawen ke spiritualitas halus yang berbasis pada praktif tasawuf/Sufisme. Berdasar hasil riset lapangan di Yogyakarta tahun 2009 dan 2010, paper ini mencoba mengungkap konteks sosiologis dari transformasi kelembagaan maupun perubahan orientasi spiritualnya di tengah proses modernisasi dan kebangkitan Islam di Indonesia pasca reformasi. Transformasi dari spiritualitas kasar ke spiritualitas halus ini terjadi, diantaranya, dilatari oleh nalar untuk menyesuaiakn praktik dan layanan spiritual agar lebih sesuai dengan alam pikiran dan kebutuhan manusia modern dan praktik spiritual yang tidak bertentangan dengan ortodoksi keberagaan umat Islam. Transformasi yang terjadi di BN telah mengantarkan kelompok spiritualitas hibrida ini untuk menawarakan formula spiritual yang lebih pro aktif dalam menyongsong peluang yang ditawarkan modernitas, bukan formula spiritualitas untuk melawan tantangan dan menghidnari tekanan kehidupan modern.

Keywords: Javanese occultism; Modern life; Hybrid Sufism; Spirituality

\section{Introduction}

The current appearance and trend of commodification as well as commercialization of spiritual efficacies in many spiritual centres as those easily found in spiritual magazines, tabloid and newspapers, which looks Islamic, in fact, grows out of a highly problematic cultural complex within the tradition of kejawen [Javanese spiritual practices], klenik or occultism. The spiritual efficacies of the group have been reshaped as 'modern and Islamic' by linking them to the notions of 'spirituality' and Sufism. It seems that 'spirituality,' loosely associated with Sufism and therefore with Islam, is now being used by many group to legitimize and popularize occultism.

Based on my field work in Yogyakarta, this paper presents a case study of the Bhakti Nusantara [BN] as a new type of spiritual centre shifting from spiritual kasar [tough spirituality] associated with occult practices, to spiritualitas alus [gentle spirituality] associated with Sufism. I will show how the spiritual tenor of the group changes from, 'hard occultism' (pro- 
moting kanuragan [martial arts and supernatural power], kekebalan [invulnerability], kesekten [extra ordinary power] and tenaga dalam [inner power]), to 'soft occultism' by proposing soul power therapy based on Sufi litanies [dhikr]. The group is re-linking to Islam, practices which had become dissociated from it. As a result, spiritual products and services are promoted as being more Islamic and socially appropriate to modern lives. In a broader context, the transformation indicates the changing responses of the spiritual group to modernity-from resisting its pressures and challenges, as some Javanese spiritual groups did, to getting involved in the opportunities presented by modern life.

\section{The Bhakti Nusantara: key figure and history}

The main figure behind the Bhakti Nusantara $(\mathrm{BN})$ is Muhammad Basis, born in Brebes, Central Java, in 1966. Basis is a well-educated middleclass person who was attracted to the fringe of Javanese culture. He was able to gain some social prominence as a counter cultural figure but he was smart enough to avoid linking himself too closely to concepts (e.g. tenaga dalam [inner power], klenik, occultism) that would attract criticism from the mainstream middle class from which he came. He was also able to adapt his teaching in his group to appropriate new concepts and religious trends emerging as popular culture changed.

Basis claims to have started training in the supernatural and martial arts when he was in the fifth grade of elementary school. Initially his parents did not allow him to learn occultism, because in his village many people used occult formulas, such as gendam [magic-hypnotism], anti bacok [anti jabbing], and bisa menghilang [disappearing] mostly for criminal actions. Without his parents' approval, Basis secretly kept going to learn, seeing almost all orang sakti [magic man] in Brebes. He would leave his home in the middle of the night and return in the morning. To finance 
his training in the supernatural, he stole neighbourhood property, such as mangos, bananas and rice, and sold them in the market. ${ }^{1}$

When Basis was in the second grade at the Madrasah Tsanawiyah [Islamic Junior High School], he demonstrated his supernatural power and martial arts prowess by eating glass and stabbing his stomach with a sabre $^{2}$ at the school farewell ceremony. His father, who was the principal of the school, was shocked. He summoned Basis and interrogated him about his ability to perform such acts. After hearing the explanation of Basis's motives for learning and mastering occultism, his father agreed to Basis's study.

After finishing junior high school in Brebes, Basis went to Yogyakarta for his senior high school and university education. He graduated from the Madrasah Aliyah Negeri [the State Islamic Senior High School] 1 Yogyakarta in 1985, and from the undergraduate program of the Department of Arabic Literature, Faculty of Art and Literature Gadjah Mada Univerity in 1991. In 1993, Basis finished his MBA (Master of Business Administration) program from HIPMI-IBMI Jakarta.

At school and at university, Basis was known as a student activist, involved in a number of student organizations. He was a chief of OSIS (Organisasi Siswa Intra Sekolah [the Inter-School Student Organization]) at his junior and senior high schools. At university, he was the university student senate chairman [ketua senat mahasiswa], and the chief editor of a student magazine, Nafiri.

While at senior high school and university, Basis continued to hone his spiritual and occult capability through various spiritual training programs, such as ilmu membuka mata ketiga [opening the third eye] and indra

\footnotetext{
${ }^{1}$ Interview with Muhammad Basis, May 18, 2010.

${ }^{2}$ Such a demonstration of invulnerability is common in shows of magical-performing art, known as the jathilan and kuda lumping, that are popular among Javanese villagers as part of kesenian rakyat [magic folk arts].
} 
ke enam [the sixth sense], and also studied at various pesantren. His spiritual journey continued after he graduated from university. Basis said: "After graduating from college, I went on studying Ilmu Hikmah Sejati [the true wisdom] in several areas of Cirebon, Kediri, Madura, Yogyakarta, Cianjur and various other cities" ${ }^{3}$. Basis also noted that he joined a tarekat [Sufi order] group in Jombang, East Java, the Shidiqiyah Sufi order, until fourth grade. ${ }^{4}$

The Bhakti Nusantara group was based on an ilham [vision] he had in a dream, before 1995. In his dream, Basis met his late grandfather, K. H. Darmawangsa, who asked him to practise and promulgate his spiritual capability by setting up a perguruan, a spiritual training centre. ${ }^{5}$ In 1995, Basis started to initiate his group, and named it Bhakti Nusantara (literally meaning 'devotion to nation').

An official document of the group, entitled Sebuah Perjalanan Dinamisasi Bhakti Nusantara, Dulu, Sekarang dan Yang Akan Datang [A Dynamic Journey of the Bhakti Nusantara: Past, Present, and Future], written by Deni R. Sopandi, records that Basis founded his group officially on April 15, 1998, in Yogyakarta. The document also records that the group has changed from one name to another, indicating the changing of its main focus. ${ }^{6}$

In the beginning, the official name of the group was Lembaga Seni Pernafasan Meditasi dan Tenaga Dalam Bhakti Nusantara (LSPMTD BN [Institute for the Arts of Breath, Meditation and Inner Power]). In this era, the focus activities of the group were promoting aerobic gymnastics,

\footnotetext{
${ }^{3}$ Koesmoko et al., Profil Spiritualis Penerima Posmo Award 2005. NC: Posmo, 2005, 46.

${ }^{4}$ Interview with Muhammad Basis, May 18, 2010.

${ }^{5}$ Koesmoko et al. Profil Spiritualis..., 46.

${ }^{6}$ Deni R. Sopandi, Sebuah Perjalanan Dinamisasi, Bhakti Nusantara, Dulu, Sekarang $\mathcal{E}$ Yang Akan datang. Yogyakarta: Pusat Penggalian Jati Diri Bhakti Nusantara \& Jamaah Lautan Istighfar, NY.
} 
meditation, and inner power, both as a means for attaining health and for mastering supernatural power.

In 2001, LSPMTD BN changed its name to PIHTI or Padepokan Ilmu Hikmah Sejati Bhakti Nusantara [Centre for True Wisdom Knowledge of Bhakti Nusantara]. During the PIHTI era, as can be seen from its new name, the BN expanded its services to include true wisdom knowledge, which, according to Gus Muhammad Basis (GMB), is noble and wisdom knowledge inherited by walis [Muslim saints] and then passed down through generations via the mechanism of pengijazahan [direct authentication and certification from a spiritual Guru to his disciples]. The BN also offered alternative healing services, accommodating various alternative healers, such as tabib [folk healer usually based on Arabic and Indian methods], sinse [folk healer based on Chinese tradition], and ustadh ahli hikmah [master of wisdom knowledge]. In addition to healing services, the group offered training programs for alternative healers. As a balance to the alternative therapies, under it commercial institution, the Bhakti Nusantara Inc., the group started to produce and sell various herbal medicines packaged in capsules, powders, etc., as well as many other health and spiritual products.

Finally, in early 2005, the BN changed its name to PUSPA JATI or Pusat Penggalian Jati Diri [Centre for Character Building] Bhakti Nusantrara. In this era, the BN introduced the TEKAJI or Terapi Kekuatan Jiwa [Soul Power Therapy] training program, which is a self-management class combined with dhikr litanies, humanistic psychology, and meditation. The TEKAJI is now the main brand of the $\mathrm{BN}$ training program. The centre also established MASAIS or Majlis Samudra Istighfar [the Assembly of Ocean Forgiveness] whose main activities include performing collective dhikr and organizing ziarah [A. ziyāra, pilgrimage] to sacred sanctuaries of local and national Muslim saints. 
In recent $\mathrm{BN}$ publications, Basis is introduced as GUS ${ }^{7}$ MUHAMMAD BASIS, abbreviated as GMB. His full name and title, Drs. H. Muhammad Basis, MBA, MRI, is usually written below his given name. A number of attributes indicating his authority and competency in spiritual and psychological training and consultancy, in spiritual and alternative healing, as well as in Islamic music and poetry, are also frequently described, such as: the grand master of character exploration [Guru Besar Pusat Penggalian Jati Diri Bhakti Nusantara]; nationally reputed trainer of soul power therapy [trainer nasional 'Terapi Kekuatan Jiwa']; shepherd of the Assembly of Ocean Forgiveness [Pengasuh Majelis Samudra Istighfar]; master of divine and revealed therapy [ahli therapi Ilahiyah dan ilhamiah]; master of the ruqyah ${ }^{8}$ for self-cleansing [ahli ruqyah akbar 'tazkiyatun-nafs'], and shepherd of the Islamic Music Group [pengasuh group nasyid 'Eling Karepe'] for which his

\footnotetext{
${ }^{7} \mathrm{G} u$ s is an appellation to sons of kyai.

${ }^{8}$ Ruqyah [A. ruqya] is a therapy method involving recitation of certain verses of the Holy Quran. It is dedicated to supplications and is used as a means of treating sickness and other problems, mainly those caused by bad spirits, demons, and also physical diseases (MissionIslam, 2010). Some Muslim groups consider that the rugyah is an Islamic therapy method practised by the Prophet Muhammad.

${ }^{9}$ GMB's resume lists a number of books he has written, published by the Bhakti Nusantara Inc. His works show GMB's exploration of the efficacy of dhikr (in Kedahsyatan Zikir [The Virulence of Dhikr]), the importance of living in God's way (in Hidup Menuju Jalan Allah [Life to God]), management of the self (in Manajemen Jati Diri [Character Management]), and Renungan Jati Diri [Self Contemplation]). He has also released a series of audio cassettes and CDs showing his exploration of dhikr litanies, the power of the mind, and meditation as means for self-healing, character-building, and gaining success and prosperity in this world. These include: Manajemen Jati Diri [the management of character]; Meditasi Penyembuhan Diri [meditation as a means of self healing]; Menemukan Jati Diri melalui Meditasi Zikir [zikir and meditation as means for character building]; Raih Sukses dengan Kekuatan Pikiran [maximising the power of mind for success]; and Penyembuhan Stress dengan Meditasi Jati Diri [self meditation as a means of stress management]. In addition, GMB is also described as Managing Director of the Lembaga Latihan Kerja Cipto Bhakti Husodo [Bhakti Husodo Institute for Employee Training] Yogyakarta, President of Himpunan Lembaga Latihan Seluruh Indonesia (HILLSI [Association of Indonesian Training Institutions]), Chief of Institut Ju Jitsu Indonesia (IJI [Institute for Ju-Jitsu Martial Arts]) Yogyakarta region, Chief of 'ZAM-ZAM' guidance group for Hajj and Umrah, the President of Majelis Persaudaraan
} 
poems were composed as lyrics. The Posmo tabloid ${ }^{10}$ attributed Basis as an internationally reputed master of the ruqyah [Ahli Ruqyah Internasional]. ${ }^{11}$

Among his community, GMB is considered as a special figure, holding a number of spiritual powers, because of which, people come to him asking for help. Deni Aden, coordinator of the BN and GBM's main assistant at the time I did field work, explained his experience before joining the group. Deni came to meet GMB about ten years ago. Deni said that he frequently lost his brand-name sandals and shoes. One day, while he was on the city bus, he read a flyer about GMB and the BN. Interested, he decided to meet GMB and ask for a solution to his problem. But Deni was disappointed, because GMB just said that his problem was a result of Deni's giving few sedekah [alms] and his infrequent dhikr. Deni had expected that GMB would tell him the name of the person who had taken his belongings. ${ }^{12}$ Although many people consider GMB as a charismatic figure, with various daya linuwih [extraordinary powers], in a number of forums GMB asserts that he is not a dukun [folk healer associated with occult practices], nor a paranormal [magician], nor a kyai. He prefers to be called just a spiritualis [spiritualist], who is not affiliated with any religious or tarikat groups.

Penyembuh Alternatif $\mathcal{E}$ Spiritualis Cinta Indonesia (MAPPATI SUCI [the Assembly Fellowship of Alternative Healers and Spiritualists of Cinta Indonesia]), and a national instructor of the workshop on 'Alpha Energy - Essential Human Consciousness'.

${ }^{10}$ Posmo, is a weekly tabloid first published on March 15, 1999, amid the uncertainty in Indonesia after the decline of the New Order era in 1998. The word 'Posmo' was taken from 'Posmodernisme' [Postmodernism]. The idea behind publishing the tabloid was to provide alternative information, when the public was overwhelmed by political news. The main contents of the tabloid are about suasana batin, spiritual, ritual dan agama [esoteric dimensions of human beings, spiritual, ritual and religious]. As stated by the editor, the tabloid addresses, as its main readers, the religious community, Javanese centrists, spiritualis [spiritualists] and paranormal, religious people, budayawan [humanists, cultural activists], historians, and academics.

${ }^{11}$ Koesmoko et al., Profil Spiritualis..., 46.

${ }^{12}$ Interview with Deni Aden, 3 November 2009. 


\section{From kasar to alus: BN's institutional and spiritual transformation}

In 2005, the Posmo tabloid awarded GMB the 'Posmo Award 2005',13 along with thirty-four Spiritualis Indonesia [Indonesian spiritualists]. In his profile, GMB was described as a figure who had been transformed from street spirituality to the Muslim way [dari spiritualitas ilmu kejadugan ke jalan Muslim]. When I clarified with him the meaning of his transformation, GMB explained it in the context of his spiritual centre. He drew an analogy between his centre's development and car speed-transmissions. GMB noted that the LSPMTD era, when the BN offered training on invulnerability and occultism [kekebalan, anti bacok, anti api, anti duri, terawangan, etc.], was the era of kejadukan. To GMB, this kind of occultism [the ilmu katosan and kanuragan] was a spiritualitas kasar, literally means 'tough spirituality', which is a very basic level of spiritual knowledge and practice, just like the first gear of a car.

Based on the LSPMTD's having operated successfully for a number of years, GMB upgraded its level to 'second gear', the PIHTI (Padepokan Ilmu Hikmah Sejati [Centre for the True Wisdom]), which promoted ilmu hikmah, the wisdom knowledge from Muslim saints. At this second level, the BN still offered kanuragan [supernatural power and invulnerability] but this was only thirty per cent of its teachings, the other seventy per cent being about the ilmu hikmah. According to GMB, the spiritual knowledge offered in the PIHTI, such as knowledge about opening indra keenam [the sixth sense] and mata bathin [inner consciousness] or mata ketiga [the third eye], was more refined than that offered in the LSPMTD. After running well in this second 'gear', the centre raised its level to PUSPA

13 The Posmo Award is a yearly award by the Posmo tabloid, dedicated to spiritualist, paranormal and alternative healers, that according to the editor, have contributed much to the development and continuation of the tabloid, by for example, advertising their spiritual programs and products in it. 
JATI (Pusat Penggaloan Jati Diri [Centre for Character Building]) and then to the MASAIS (Majelis Samudra Istighfar [the Assembly of of Ocean Forgiveness]). GMB asserted that the PUSPA JATI and MASAIS are kinds of 'spiritualitas alus' [gentle spirituality], exploring people's inner potencies and self-awareness, as well as the power of the soul.

GMB therefore underlined the fact that the development of the BN was basically a transformation from spiritualitas kasar (tough spirituality) to spiritualitas alus [gentle spirituality]. GMB also compared the development of his group to the four spiritual stages in the syari'at, tarikat, hakikat, and makrifat. The LSPMTD era was equivalent to the syari'at, the PIHTI era was the tarikat, and the PUSPA JATI era is the hakikat. ${ }^{14}$ The top level of spiritual stages in the BN is MASAIS. Why is MASAIS considered as the pinnacle of BN spiritual development? Because the main activity of MASAIS (which is an abbreviation of Majelis Samudra Istighfar [the assembly of ocean forgiveness]), is dhikr. Along with the tahmid (saying Alhamdu lillāh [Praise to be God]) and tasbiḥ (glorification of God by saying Subhāna Allah), the istighfar (saying Astaghfiru Allāh [I ask forgiveness of God]) is the most important litany intoned by the congregation during the ritual of dhikr. GMB asserts that asking God's forgiveness [istighfar] is considered the best way to purify human's sins:

"Human beings, since they were in the womb, and then are born, live, and die, naturally seek forgiveness. Whoever they are, santri [student of Islamic boarding schools], ulama [Muslim scholars], wali [Mus-

\footnotetext{
${ }^{14}$ GMB's analogy between the development of his groups and the spiritual stages in Sufi heritages is interesting. The terms Syariah [Ar. Shari' $a$, the Sacred Law], Tarekat [Ar. Tarîqa,

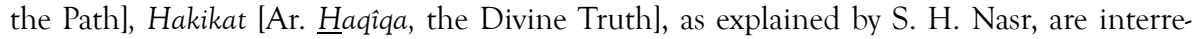
lated concepts of Muslim's spiritual stages of transformation from the 'outward' religiosity to the 'inward' one. In Islamic mysticism, the final spiritual journey is called Makrifah [Ar. Ma'rifa], which is the esoteric knowledge of God, or Gnostic. These spiritual stages refer to spiritual journeys of individual Muslims who want to transform from the exoteric expression to the esoteric one. GMB, however, explores them in the context of his institution.
} 
lim saints], etc. if they leave the istighfar, they are useless. In my opinion, the nature of life is to purify God [tasbih]. Purifying God means purifying oneself. To purify ourselves [from sins], we use istighfar." ${ }^{15}$

GMB further asserted that the changing focus of his teachings in the $\mathrm{BN}$ was nothing to do with the marketing strategy of the centre. The transformation was neither to adjust to market demands nor to follow contemporary trends. To GMB, all kinds of spiritual formulas and efficacies can be sold, depending on how they are packaged and marketed. "The transformation was rooted in [my] deep philosophical consideration," he added.

Nevertheless, in the light of broad social changes at the time, and the emergence of other similar 'spiritual training' programs, the transformation of the BN from LSPMTD to PIHTI, and then to PUSPA JATI cannot be separated from the national milieu surrounding the group. It is worth noting here that since the early and mid 2000s, various publications, including spiritual manuals, self-help therapies, and other books, have explored the importance of Spiritual Quotient [SQ] for human success (e.g. Rahasia Sukses Membangun Kecerdasan Emosi dan Spiritual ESQ (Emotional Spiritual Quotient): Berdasarkan 6 Rukun Iman dan 5 Rukun Islam [the secret of developing ESQ emotional spiritual quotient: based on the 6 principle of faith and 5 pillars of Islam] by Ary Ginanjar Agustian; ${ }^{16}$ The Power of Spiritual Intelligence: Sepuluh Cara Jadi orang yang Cerdas Secara Spiritual [ten ways of being spiritually intelligent people], by Tony Buzan; ${ }^{17}$ Jelajah Diri: Panduan Psikologi Spiritual Membangun Kepribadian [exploring

${ }^{15}$ Interview with GMB, May 18, 2010

${ }^{16}$ Ary Ginanjar Agustian, Rahasia Sukses Membangun Kecerdasan Emosi dan Spiritual ESQ (Emotional Spiritual Quotient): Berdasarkan 6 Rukun Iman dan 5 Rukun Islam. Jakarta: Arga, 2001.

${ }^{17}$ Tony Buzan, The Power of Spiritual Intelligence: Sepuluh Cara Jadi Orang yang Cerdas Secara Spiritual, A. T. Kanjono \& F. Fialita (Trans.), Jakarta: Gramedia Pustaka Utama, 2003. 
the self: a guide to spiritual psychology for self-development] by Syaikh Fadhalla Haeri $\left.{ }^{18}\right)$. The social, religious, economical, and political problems in Indonesia which came about as a result of the reformation in 1998, have, to some extent, caused national instability and raised people's awareness of the need to search for their true identity. Exploring Sufi teachings, some popular Islamic preachers, like Aa Gym, Arifin Ilham, and Yusuf Mansur, emphasized their dakwah on the importance of introspection, self-management, and self-empowerment. A Jakarta based spiritual-psychological training centre, the ESQ Way 165 of Ary Ginanjar, also started offering, nationally, an Islamized hybrid of the Emotional and Spiritual Quotient training program.

GMB's notion about the shift in his group from spiritualitas kasar to spiritualitas halus, also indicates the shift from 'hard occultism' to 'soft occultism' which is framed with practical Sufism, that makes the centre appear even more Islamic than before. The BN's iconic program is no longer based on breath control or cultivating one's inner power and other supernatural powers [kanuragan], but on TEKAJI (Terapi Kekuatan Jiwa [Soul Power Therapy]) based on dhikr litanies for this-worldly success. The TAKEJI program coordinator, Helmi Santoso, in his press release about the training program, explained that TEKAJI is dedicated to uncovering the secret of human character through cultivating spirituality, in order to strengthen self-awareness and self-control, to attain soul serenity, and to optimize the mind and the spirit for success. Hilmi further added that the training is also effective as a way of solving various problems, such as feeling sickly, nervous or restless, and for eliminating bad habits, such as laziness and lack of discipline. ${ }^{19}$

\footnotetext{
${ }^{18}$ Syaikh Fadhalla Haeri, Jelajah Diri: Panduan Psikologi Spiritual Membangun Kepribadian. Jakarta: Serambi, 2004.

${ }^{19}$ Kedaulatan Rakyat, Thursday, April 15, 2010.
} 
About the trend that is now making the BN more Islamic, Deni Aden, the $\mathrm{BN}$ coordinator, explains:

"Having witnessed numerous events and activities, I think there have been quite drastic changes since the era of Puspa Jati Bhakti Nusanta. In the past, BN used to offer gemblengan and pengisian [supernatural training and recharging], which is more on kanuragan [invulnerability] trainings, but these have been slowly reduced. This is not because of a decrease in enthusiasm. There are even still many people who want such invulnerability programs.

After GMB performed Hajj, in around 2005, there was a kind of obligation [to appear more Islamic]. Thousands of people have participated in various $\mathrm{BN}$ programs and activities, so why don't BN use them as media of dakwah [Islamic preaching]? All BN committees are Muslim, although the followers or members are not necessarily so. It is therefore understandable if the image of $\mathrm{BN}$ is now that of an Islamic institution. I think such an image is better rather than $\mathrm{BN}$ being considered as an unclear institution... Nowadays, almost ninety per cent of BN activities are Islamic."20

The face of Islam also appears on the BN's name board in which the group deliberately puts the words Islami [Islamic] and syar'iyah [appropriate to shari'ah] after programs and products of the BN, such as Pusat Penggalian Jati Diri Islami [Centre for Islamic Character Exploration], Pelatihan Penyembuhan Alami $\mathcal{E}$ Islami [Training for Islamic and Natural Healing], Sedia Kaset-Kaset Zikir/Spiritual Islami, and Majelis Ruqyah Syar'iyah [Assembly for Ruqyah Syar'iyah].

Aden also confirmed that since the PUSPA JATI era, under coordination by MASAIS, the BN introduced collective dhikr as one of its healing techniques. The assertion of the importance of individual dhikr was actually already implemented in the era of the LSPMTD and the PIHTI.

${ }^{20}$ Interview with Deni Aden, 3 November 2009. 
However, since the PUSPA JATI era, the BN has implemented the healing dhikr in more systematic ways, organizing the ritual regularly and collectively, and spreading the formula of the healing dhikr through audio CDs and other means.

The MASAIS activities for organizing collective healing dhikr, when examined in a broader context, cannot be separated from the mushrooming of majlis dhikr groups in Indonesia since 2005, some of which have been aired on national televisions. Among popular groups and figures are Arifin Ilham of Majlis Dhikr Az-Zikra and Ustadh Haryono of Majlis Dhikr Nurul Jannah.

Another colouration of Islam appears in the BN program of ziarah to the graves of the wali [Muslim saints]. In Javanese society, pilgrimage to the ancestral sanctuary is part of spiritual efforts to solve "problems of everyday life that cannot be solved in the usual social environment." 21 The Javanese spiritual world, basically, cannot be separated from the activity of this pilgrimage. ${ }^{22}$ Understanding the needs of its congregation, the BN has, on a number of occasions, successfully organized collective ziarah to several walis' tombs, giving new meaning and purpose to the ziarah.

Ziarah is commonly performed for the purpose of ngalap berkah [asking blessing]. Some pilgrims follow orthodox practices, asking for bless-

${ }^{21}$ H. Chambert-Loir \& C. Guillot, "Indonesia”, J. Couteau et al. (Trans.), in H. ChambertLoir \& C. Guillot (Eds.), Ziarah \& Wali di Dunia Islam. Jakarta: Serambi, 2007, 357.

${ }^{22}$ Among the Javanese, either santri [devoted Muslim], priyayi [aristocrats], or abangan [ordinary people with a lessening devotion to Islam in favour of local customs] (to borrow Geertz's trichotomy of Javanese socio-religious polarization), ziarah is an important spiritual journey to gain barokah (God's reward transmitted through the wali), keprajan, or perolehan (inner worldly success). It was believed that every sacred tomb had a specific efficacy. Some people feel cocok (compatible with) and jodo (in partnership with) toward certain sacred tombs but not others. If one gets perolehan [gain a result] after doing ziarah, it means the particular sacred tomb attended is compatible [cocok] with her/him. For further discussion on various meanings of ziarah in Java, see Jamhari, "The Meaning Interpreted: The Concept of Barokah in Ziarah," Studi Islamica, 8 (2001), 87-128. 
ing from God, but many ask for it from their ancestors. They ask for thisworldly success, such as gaining keprajan [rank and degree in career], ${ }^{23}$ being successful in business, or acquiring a certain spiritual power. According to the $\mathrm{BN}$, the true purpose of ziarah is not to request blessings from the ancestors or wali, but from God. The prayer during ziarah should be directed to God, instead of to the ancestors. GMB explains that the reason for performing ziarah is to look for the place which has the highest spiritual energy. Muslim saints' sanctuaries are, according to GMB, among locations accommodating high spiritual energy that make the prayers conducive to a response from God [mustajab]. Before the ziarah, GMB frequently reminded his congregation of its right meanings and purposes, so that they would have the correct intention [niat] and avoid misunderstanding of the BN ziarah program.

In his paper, entitled 'Ziarah Wali Songo' [pilgrimage to the nine Muslim saints], GMB argues that ziarah is not syirik ${ }^{24}$ (A. shirk, heresy) and, furthermore, that it it is recommended that Muslims do the ziarah, especially to the tombs of Muslim saints. However, he also admitted that there are many ziarah practitioners who perform falsely.

"It is understandable that there is a stigma which prejudices some people against ziarah rituals. We do not close our eyes to the fact that

${ }^{23}$ Javanese society believes that every sanctuary is beneficent in several ways. It is commonly understood that those who want to acquire keprajan [preferment], should do ziarah to the Petilasan Parangkusumo, a stone in Parang Kusumo beach believed to be the meeting point of Panembahan Senopati, the ancestor of the Islamic Mataram Kingdom in Yogyakarta, and the Ratu Kidul, which literally means the 'Queen of South', the spiritual guardian of the South Sea of Java. See Gatot Murniatmo et al., Budaya Spiritual Petilasan Parangkusumo dan Sekitarnya. Yogyakarta: Kementerian Kebudayaan dan Pariwisata, Deputi Bidang Pelestarian dan Pengembangan Kebudayaan, Balai Kajian Sejarah dan Nilai-nilai Tradisional Yogyakarta, Proyek Pemanfaatan Kebudayaan Daerah, Daerah Istimewa Yogyakarta, 2003.

${ }^{24}$ Syirik (A. Shirk) is associating or putting something or someone in the place of God thus deviating from the principle of tauhîd or monotheism in Islam (see the meaning of Shirk, in the Oxford Dictionary of Islam). 
many people do commit heresy, even syirik in their ziarah. They go to the tombs bringing offerings. As such, it is, Insha Allah, heresy. Worse still, they are crying, appealing to the body that lies in the grave. That is a serious syirik. According to the teachings of the Prophet Muhammad, one who goes to the tomb is obliged to: (1) say salam [greeting] to the deceased in the grave; (2) pray for the occupant of the tomb; (3) read the prayers that are taught of God through His messenger; (4) pray fervently for the sake of goodness in the world and the hereafter. The Prayer is intended only to God Almighty; do not plead to the occupant of the grave...Praying at the tombs of the saints of God is an effort to make our prayers efficacious. We pray to God in the holy tombs, in order that our wishes may be granted by Allah SWT."25

The above quotation implies that GMB asserts the BN ziarah program to be legitimate, free from heresy, unlike the ziarah usually performed by Javanese practitioners of occultism. In addition to explaining to the public that the $\mathrm{BN}$ ziarah program is not in contradiction to Islamic principles, GMB teaches his congregation how to perform ziarah correctly. This is important in the context of Yogyakarta, where a number of puritan Muslims and Salafi oriented groups still argue that ziarah rituals tend to lead to syirik practices.

\section{The Javanese occult practices, modern life and Islamic revival}

Based on the above explanation, it is fair to say that in its social context, the transformation from kasar to alus has made the public face of the BN appear more Islamic, resembling orthodox Sufism. What does the BN's transformation from spiritualitas kasar to spiritualitas alus mean in the context of Indonesian Islamic revival? At first glance, it shows the BN's strategy in reshaping its occult practice in order to be included under the

${ }^{25}$ Gus Muhammad Basis, Ziarah Walisongo, Panduan Ziarah Wali Songo Angkatan 15, 25-27 January, 2008. Yogyakarta: Bhakti Nusantara, 2008. 
'brand' of orthodox Islam. But why should the BN do this? To understand, we need to consider the historical conflict between Javanese occult practices and modern life in Indonesia.

In its March 12, 1983 edition, under the title 'Praktek Dukun Modern' [The Practice of the Modern Shaman], Tempo, a top national magazine, reported the use of occultism for secular activities, such as recruiting employees, mapping oil mining fields, finding lost airplanes, predicting the composition of a new cabinet team, as well as relieving diseases that doctors could no longer handle.

Among several figures implementing spiritual practices and efficacies in business industries, is Sabdono Surohadikusumo, owner of real estate, catering, and general trading companies. In his interview with Tempo, Sabdono testified that mystical meditation had saved him from bankruptcy in the 1970s. ${ }^{26}$ Because of his experiences, Sabdono hoped the Indonesian government would use the spiritual efficacies mastered by Indonesian spiritualists [paranormall. Sabdono was, in fact, one of the initiators of an organization of Indonesian paranormals. He was the leader of the Yayasan Parapsikologi Semesta (literally meaning 'the foundation of universal parapsychology').

Tempo also reported on business managers, who met at Jakarta, not for discussing the business prospects or assets of the company, but for meditating in order to meet their ancestors. The managers reported to their ancestor's spirits, who came to them in a vision, on the development of their company, and asked about the possibilities of future plans. The meditation even went so far as to discuss with the spirits when the company should hire new employees. Sabdono, among businessmen pioneering the implementation of both modern management and mystical

\footnotetext{
26 Tempo, March 12, 1983, 65.
} 
meditation, said: "If we want to hire someone for the level of staff managers, we also meditate. Vibrations we got from the meditation often suggested that these people should not be accepted because they were spendthrifts. It would be better to hire another person who is more reliable". Sabdono further testified that running his business based only on modern management skills was not a guarantee for success. "Operating by normal business procedures caused my company to suffer the loss of two billion rupiah in 1976. Later on, I implemented meditation, which was used to attain peace of mind in my business." 27

Tempo's report indicates the blending of something like occult practices with modern management, in a modern capitalist enterprise. The practice, however, seems to be rooted in non-specific religious traditions. It reflects the practice of Javanese spirituality of the kebatian. The absence, in the report, of any reference to Sufi elements, might be because Sufi heritage practices in the early 1980s were still mostly carried out in a number of pesantren, established in rural areas. Furthermore, Indonesian discourses of Sufism, in this era, were still dominated by the notion that Sufism was incompatible with modern culture.

Currently, Sufi heritage traditions are flourishing in urban areas, manifested in the various hybrid groups of the Islamic spiritual centres, such as the majlis dhikr groups and other urban Sufi groups trying to avoid their spiritual expressions being considered as heresy. Many of these urban Sufi groups are even depicted as pro the modern culture. It seems to me, therefore, that the popularity of orthodox Sufi groups in the last two decades in Indonesia has pressured the heterodox Islamic spiritual groups to change their orientation, giving their occult based spirituality a more orthodox appearance.

\footnotetext{
${ }^{27}$ Tempo, March 12, 1983, 65-66.
} 
In the context of Indonesian Islam in general, the shift from occultism to Sufism, as happened in the BN, indicates two possibilities. First, the transformation is a further step, or at least a different path, towards fuller engagement with normative Islam, rather than merely a dialectical process between the Javanese kebatinan and Islamic spirituality, as indicated by Stange $(1986,1998) .{ }^{28}$ Unlike Subagya (1981) and other scholars who regard kebatinan as a 'rival' of Islam, or another dimension of Islam, instead of being an integral part of it $^{29}$, Stange asserts that Sufism, both at an esoteric level and as a philosophical mystique, has been absorbed in the inner dimension of the Javanese. ${ }^{30} \mathrm{He}$ also notes that the Islamization of Java has reached even to the "recesses of Javanese spiritual life":

"When we approach Islam as a mode of discourse and inner orientation, rather that in strictly doctrinal and ritual terms, it becomes evident that the Islamization of Java has reached farther into the recesses of Javanese spiritual life than we would otherwise suspect." 31

However, if Islam has already been absorbed into the deep religious practices of Javanese people, why should a spiritual group like the BN still be trying to Islamize Javanese occultism? Perhaps the answer to this question can be traced back to the unclear theological status of the boundary between occultism and Sufism-mysticism. While the practice of teaching and learning about supernatural powers, invulnerability and many 'magical' formulas is still broadly performed by popular Sufism-mysticism, under the umbrella of ilmu hikmah, the Muslim reformers tend to see the practice as syirik [deviationist], indicating a blending of magic, sorcery,

\footnotetext{
${ }^{28}$ See Paul D. Stange "”Legitimate” Mysticism in Indonesia”, Review of Indonesian and Malaysian Affairs, 2 (Summer 1986) and Paul Stange, Politik Perhatian: Rasa dalam Kebudayaan Jawa, In H. Salim (Ed.), Yogyakarta: LKiS, 1998.

${ }^{29}$ R. Subagya, Agama Asli Indonesia, Jakarta: Sinar Harapan, 1981.

30 Stange, Politik Perhatian..., 244.

${ }^{31}$ Stange, "Legitimate" Mysticism in Indonesia..., 107.
} 
and Islamic mysticism. The government, as one of the sponsors of modernization, also regards magical practices as backward, ${ }^{32}$ potentially hindering state development. From this perspective, the Islamization of occultism in the $\mathrm{BN}$ seems to be about contesting whether occultism is lawful and permissible in Islam.

In the case of the $\mathrm{BN}$, when I sought to confirm from GMB the matter of transformation from occult to the more Sufi oriented practices, he did not explicitly answer from a perspective of Islamic theological discourse. Rather, he explained it from his dakwah strategy, saying that in the past, occult practitioners were close to criminals. People studied invulnerability and other supernatural powers to facilitate their criminal actions-for example, swindlers, pickpockets, thieves, and robbers. To GMB, mastering occultism was a starting point for his dakwah. It was just another way to call people to Islam. Once they were in the $\mathrm{BN}$ members group, they would be led to the 'true Islam'. ${ }^{33}$

Thus it can be said, that Islamization, in terms of increased Islamic expression, occurs not only in political arenas and in other symbolic appearances in public spheres, but also in the inner dimension of spiritual expression associated with occult practices. The more visible picture of Islam in Indonesian public life, after the collapse of the New Order regime in 1998, has driven a number of Islamic groups to present their version of 'true Islam'. Interestingly, the contest is taking place not only in the political field and in people's outer appearances, but also in their inner spiritual world. Based on his fieldwork, Timothy Daniels finds what he calls 'Contesting Islamic Discourse' among alternative healers in Yogyakarta associated with Javanese occult dukun, Sufis kyai and salafi-

32 DS Farrer, Muslims in Global Societies Series: Shadows of the Prophet, Martial Arts and Sufi Mysticism, Springer, 2009, 52-53.

${ }^{33}$ Interview with GMB, May 18, 2010. 
oriented ustadh. Even alternative healers associated with dukun, orang pintar or paranormals, whose practices are totally rooted in kejawen occult science, claim that their services are 'Islamic'. To convince the Muslim community of this, they go so far as to adopt Islamic instruments in their alternative clinics. ${ }^{34}$

In a more symbolic way, the Islamization of Javanese occultism also occurs among other Indonesian paranormals promoting their spiritual efficacies in tabloids or magazines. For example, the Liberty magazine shows a woman with jilbab [headscarf] advertising her spiritual centre, the Padepokan Mama Hajjah Sri Maslachah, and promoting ruwatan services to solve various problems in areas such as career and love. The insertion of 'Hajjah' before her name asserts that she is religiously good, because she has performed a pilgrimage to Mecca. Likewise, another advertisement depicts a woman spiritualist with jilbab, known as Mama Sri, promoting her ability to provide services for pagar gaib [supernatural protection], pengasihan [attracting love], and kemakmuran [increasing prosperity]. ${ }^{35}$ Such symbolic Islamization is not exclusive to female spiritualists. For male spiritualists, Islamization was achieved, for example, by adding 'Gus' [son of a kyai] before their real name, wearing a turban, holding chaplet for dhikr (tasbih) and other Islamic symbols.

The second possible meaning of the transformation from occult based spirituality to the more Sufism-oriented spirituality is that it shows a continuation of the contest between Islamic spiritual efficacies and local occultism, in the secular arena. Looking at advertisements in local publications in Yogyakarta, such as Kedaulatan Rakyat, Merapi, and Minggu Pagi, one will easily find advertisements promoting various occult products like pengasihan, penglaris, buka aura, pasang susuk, tolak bala, [attracting love,

\footnotetext{
34 Timothy Daniels, Islamic Spectrum in Java, Burlington: Ashgathe, 2009, 55-80.

35 Liberty, July 12-20, 2010, 94, 119.
} 
attracting customers, opening one's aura, installing spiritual implants, protecting oneself from any misfortunes] and other alternative healings. To Muslim spiritualists, these promoted occult spiritual products are regarded as unauthentic and, for some orthodox groups, are even categorized as shirk. Nevertheless, their caution is not effective in protecting the ordinary Muslim from dealing with these occult practices. Having transformed to Sufi oriented spirituality, the BN, as an Islamic spiritual centre, tries to provide spiritual efficacies which are claimed to be more Islamic, more religiously valid, and better, than the regular 'occultisms' offered by dukun and paranormal. Some Indonesian Muslim spiritual practitioners, like GMB, dream of transforming Indonesian public life from dukun to Islamic spirituality.

\section{Conclusion}

The BN's transformation from spiritualitas kasar [rough spirituality] of occult-based spirituality to the finer spirituality [spiritualitas alus] which is linked to Sufi spiritual practices, as well as the changes of groups names and spiritual orientation has led the group to package diverse spiritual programs and products, shaped in line with the current development of spirituality in Indonesia. The BN's organizational transformation, and the change in its focus of spirituality from the kasar to the alus was, in some respects, driven by the logic of presenting spiritual heritages that are practically appropriate for modern life and which also fit religiously with orthodox Islam. These changes mark BN, as an Islamic based hybrid-spiritual group, to actively involve in the opportunities of modernity by promoting spiritual formula for gaining its merit, instead of resisting the challenges and pressures of modern life. 


\section{Bibliography}

Agustian, Ary Ginanjar. Rahasia Sukses Membangun Kecerdasan Emosi dan Spiritual ESQ (Emotional Spiritual Quotient): Berdasarkan 6 Rukun Iman dan 5 Rukun Islam. Jakarta: Arga, 2001.

Basis, Gus Muhammad. Ziarah Walisongo, Panduan Ziarah Wali Songo Angkatan 15, 25-27 January, 2008. Yogyakarta: Bhakti Nusantara, 2008.

Buzan, Tony. The Power of Spiritual Intelligence: Sepuluh Cara Jadi Orang yang Cerdas Secara Spiritual. A. T. Kanjono \& F. Fialita (Trans.). Jakarta: Gramedia Pustaka Utama, 2003.

Chambert-Loir, H. \& C. Guillot. "Indonesia”, J. Couteau et al. (Trans.), in H. Chambert-Loir \& C. Guillot (Eds.). Ziarah E Wali di Dunia Islam. Jakarta: Serambi, 2007.

Daniels, Timothy. Islamic Spectrum in Java. Burlington: Ashgathe, 2009.

Farrer, D.S. Muslims in Global Societies Series: Shadows of the Prophet, Martial Arts and Sufi Mysticism. Springer, 2009.

Haeri, Syaikh Fadhalla. Jelajah Diri: Panduan Psikologi Spiritual Membangun Kepribadian. Jakarta: Serambi, 2004.

Interview with Deni Aden, BN coordinator, 3 November 2009.

Interview with Muhammad Basis, May 18, 2010.

Kedaulatan Rakyat, Thursday, April 15, 2010.

Koesmoko et al. Profil Spiritualis Penerima Posmo Award 2005. NC: Posmo, 2005.

Jamhari. "The Meaning Interpreted: The Concept of Barokah in Ziarah," Studi Islamica, 8 (2001): 87-128.

Liberty, July 12-20, 2010.

Murniatmo, Gatot et al. Budaya Spiritual Petilasan Parangkusumo dan Sekitarnya. Yogyakarta: Kementerian Kebudayaan dan Pariwisata, Deputi Bidang 
IJIMS, Indonesian Journal of Islam and Muslim Societies, Volume 4, Number 1, June 2014: 81-104

Pelestarian dan Pengembangan Kebudayaan, Balai Kajian Sejarah dan Nilainilai Tradisional Yogyakarta, Proyek Pemanfaatan Kebudayaan Daerah, Daerah Istimewa Yogyakarta, 2003.

Nasr, S. H. "The Interior Life in Islam", Al-Serat: A Journal of Islamic Studies III ( $2 \&$ 3). Retrieved October 12, 2011, from http://www.al-islam.org/alserat/

"Shirk", in The Oxford Dictionary of Islam. Oxford Islamic Studies Online. Retrieved October 10, 2011, from http://www.oxfordislamicstudies.com/ article/opr/t125/e2195

Sopandi, Deni R. Sebuah Perjalanan Dinamisasi, Bhakti Nusantara, Dulu, Sekarang E Yang Akan datang. Yogyakarta: Pusat Penggalian Jati Diri Bhakti Nusantara \& Jamaah Lautan Istighfar, NY.

Stange, Paul D. "'Legitimate” Mysticism in Indonesia”, Review of Indonesian and Malaysian Affairs, 2 (Summer 1986).

Stange, Paul. Politik Perhatian: Rasa dalam Kebudayaan Jawa, in H. Salim (Ed.). Yogyakarta: LKiS, 1998.

Subagya, Rachmat. Agama Asli Indonesia. Jakarta: Sinar Harapan, 1981.

Tempo, March 12, 1983. 